\title{
Comparative Study of Rectenna for Electromagnetic Energy Harvesting ${ }^{*}$
}

\author{
Sajina Pradhan ${ }^{1}$, Seong-Ro ${ }^{2}$, Lee Sun-Kok Noh ${ }^{3}$ and Dong-You Choi ${ }^{4}$ \\ ${ }^{1}$ Department of Mechatronics Engineering, Chosun University \\ ${ }^{2}$ Department of Information and Electronics Engineering \\ ${ }^{3}$ Mokpo National University \\ ${ }^{4}$ Department of Photoelectronics Information, Chosun College of Science \& \\ Technology, (Corresponding Author)Department of Information and Communication \\ Engineering, Chosun University \\ ${ }^{1}$ srlee@mokpo.ac.kr, ${ }^{2}$ sajinapra@hotmail.com, ${ }^{3}$ nsk7078@hanmail.net, \\ ${ }^{4}$ dychoi@chosun.ac.kr
}

\begin{abstract}
In this paper, we present the review of energy harvesting contained in electromagnetic waves. An overview of existing energy harvesting techniques is discussed, which will motivate researchers to design antenna in the field of electromagnetic energy harvesting. It also focuses on a characteristic of patch antenna for designing Rectenna.
\end{abstract}

Keywords: Wireless power transmission, Radio frequency $(R F)$, Energy harvesting, Rectenna

\section{Introduction}

In our daily life, wireless technology has become a popular means of transmitting signals from the use of satellite in space to the use of cell phones. Anybody, anywhere and anytime wireless technology has provided the easiest way to us. In the present situation where the production of energy is reliant on gas and oil industry whose price is irregular daily, the wireless energy concept may be used as alternative energy. Awareness regarding need to reduce our reliance on fossil fuels has led to the development of surrounding self-regenerating energy source.

Many researches and efforts are being conducted to develop a technique to supply power to the electrical and electronics equipment using energy harvesting technology. In this modern era, electronic appliances grow along with radiation, although most radiation from these electronic devices is harmless, the radiated energy is not being utilized, and thus a device capable of harvesting energy can be built.

The wireless energy transfer is a process that takes place in any system where electrical energy is transmitted from a power source to an electrical load, without involving wires. Wireless transmission is ideal in cases where instantaneous or continuous energy transfer is needed, whereas wired connections are inconvenient, hazardous, or impossible [1]. Though the physics of both are related, this is different from wireless transmission for the purpose of transferring images such as television broadcasting, where the percentage of the received power is only important if it becomes too low to successfully recover the signal. With

* Work presented in part at the ICCA 2013, Jeju Island, Korea, November 2013 
wireless energy transfer, the efficiency is a more critical parameter and creates important differences in this technology [2].

\section{Ambient Energy Sources and Techniques}

Energy sources surrounding everywhere around us in the environment are available in the form of light, thermal, wind, mechanical, or electromagnetic energy. Energy harvesting, power harvesting or energy scavenging is the process of collecting and capturing ambient energy in order to make new things possible and to remove the expense, inconvenience and pollution that results from frequent replacement of batteries in small devices. Wireless power transmission has received significant attention in the past demonstrating efficient RF to DC conversion capability for direct, high power transmission applications. Recently, considerable many research efforts have been done to harvest ambient energy from solar energy, microwave energy to employed existing communication networks [3-6].

Ambient RF energy is pervasive, especially for mobile and Wi-Fi networks. ABI Research and iSupply estimate that mobile-phone subscriptions have surpassed 5 billion, and the ITU estimates there are over 1 billion mobile broadband subscriptions. RF energy can be harvested from mobile phones in close proximity, potentially providing power-on-demand for shortrange sensing applications. Other sources of RF energy such as Wi-Fi routers and wireless end devices (i.e., Laptops) are also plentiful. At short range, such as within the same room, users can harvest a small amount of energy (microwatts) from a typical WI-Fi router transmitting at $50 \mathrm{~mW}$ to $100 \mathrm{~mW}$. For long-range operation, higher-gain antennas are needed to harvest RF energy from mobile base stations and broadcast radio towers [7].

Antenna as the communication device is used for transmission and/or reception of data by utilizing the different frequency ranges. Frequency ranges and power at different frequency spectrum from $10 \mathrm{kHz}$ to $30 \mathrm{MHz}$ are given in detail in [8]. The output power of RF devices is limited due to safety and health concern offered to EM radiation by regulations such as Federal Communications Commission (FCC), USA [9]. The maximum theoretical available power for RF energy harvesting is $7.0 \mu \mathrm{W}$ and $1.0 \mu \mathrm{W}$ for $900 \mathrm{MHz}$ and $2.4 \mathrm{GHz}$ frequencies respectively for a free space distance of 40 meters. The path loss of signals can be different in an environment other than free space [10]. The diagram of various microwave power sources along with their typical density levels is shown in Figure 1.

Energy harvesters do not provide enough amount of power to produce mechanical movements or temperature changes (like cooks, refrigerators, etc.) because there are no such technologies that can capture energy with that much of great efficiency. But these technologies can provide the amount of energy sufficient enough for low-power devices that can operate separately. Another advantage with this type of technology is that, unlike the production of large-scale power, we can get the free energy source from the electromagnetic energy of transmitting mobile stations, radio, and TV broadcasting antennas.

A number of studies and a los of surveys have already been done in this literature. In [11], a new method to find a maximum power point of sensor nodes using renewable energy has been proposed in order to extend the sensor node's life. A maximum power point refers to a point, at which a sensor node's power becomes a maximum through the proper ratio between a voltage and a current. In [12], Through SPICE simulation, different piezoelectric harvester interface circuits are demonstrated and compared. In [13], a new way of representing and interacting with energy in electric products, specifically home appliances has been developed. 


\section{Rectenna Concept and Brief Literature Review for Electromagnetic Energy Harvesting}

Rectenna is an acronym for RECTifying antenna as shown in Fig.2 [6]. It is a particular type of antenna that rectifies the incoming electromagnetic waves into DC current. Usually, a rectenna consists of a mesh of dipoles and diodes for collecting microwave energy from a transmitter and then converted it into electric energy. The elements are commonly arranged in a mesh pattern giving a district appearance from most antennas. A simple rectenna can be made from a schottky diode placed between antenna dipoles. Antennas can be considered as the backbone in the wireless communication without which the world would not have reached till this age of technology. The rectification of microwave signal to DC power has been proposed and researched since the 1950s [14] in the context of high power beaming. It has been proposed for helicopter powering [15], solar power satellite (SPS) [16], the SHARP (Stationary High Altitude Relay Platform) System [17], and recently for RFID system. In 1999, the Korea Electro technology Research Institute conducted a study on the wireless power transmission system, where they were able to achieve single rectenna conversion efficiency of $75.6 \%$ and an overall system efficiency of 33\% [18] .There are many research work related to rectenna elements. The antenna can be any type such as dipole [4,19], YagiUda antenna [20, 21], microstrip antenna [22, 23], monopole [24], loop antenna [20, 25], coplanar patch [26], spiral antenna [27], or even parabolic antenna [28]. The rectenna can also take any type of rectifying circuit such as single shunt full-wave rectifier [29-34], full-wave bridge rectifier [34-37], or other hybrid rectifiers [22]. The circuit, especially the diode is used to determine the RF-DC conversion efficiency. Silicon Schottky barrier diodes were usually used before for the previous rectennas but these days new diode devices like Silicon Carbide and Gallium Nitride ( $\mathrm{SiC}$ and $\mathrm{GaN}$ ) are expected to increase the efficiency. The rectennas with FET (Field Effect Transistor) [38] or HEMT (High Electron Mobility Transistor) [39] appear in recent years. The world record of the RF-DC conversion efficiency among developed rectenna is approximately $90 \%$ at $4 \mathrm{~W}$ input of $2.45 \mathrm{GHz}$ microwave [35]. Other rectennas have approximately $70-90 \%$ at $2.45 \mathrm{GHz}$ or $5.8 \mathrm{GHz}$ microwave input. The comparative summary of rectenna designs for electromagnetic energy harvesting is shown in Table 1 [40].

In 2009, students of Singapore of the Nanyang Technology University conducted a study in which they attempted to use wireless energy technology to remotely power sensors with low amount of energy. They used patch antennas to receive the signal and rectenna was used to rectify the power. They found that the addition of a low pass filter helped concentrate the power received and improved the overall efficiency of the system [41].

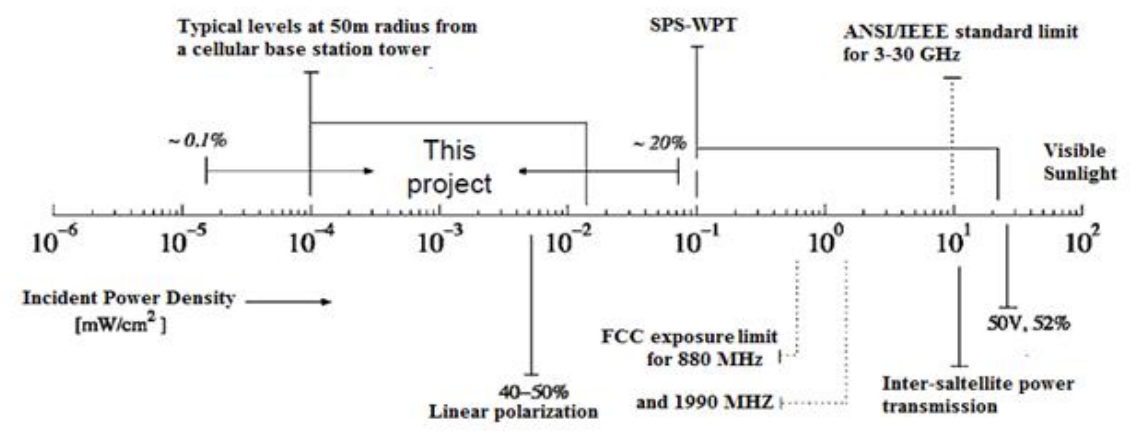

Figure 1. Various microwave power sources and their typical power density levels 


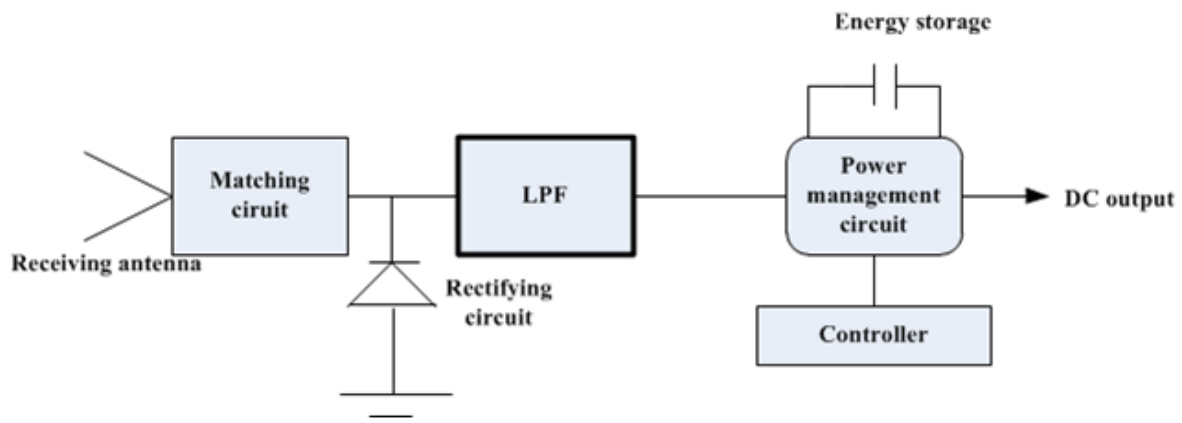

Figure 2. Basic rectenna schematic with the power management system

The RF-DC conversion efficiency $\eta$ is represented as follows:

$$
\eta=\left(\left(\mathrm{P}_{\mathrm{DC}}\right) /\left(\mathrm{P}_{\text {Received }}\right)\right) * 100 \%
$$

where, $P_{D C}=V_{D C}{ }^{2} / R_{L}, V_{D C}$ is the output DC voltage at the load, $R_{L}$ is the load resistance, $\mathrm{P}_{\text {Received }}$ is the available power at the input of the rectifier.

Table 1. Comparative summary of rectenna designs for electromagnetic energy harvesting

\begin{tabular}{|c|c|c|c|c|c|}
\hline Author(year) & Type & Design & Power input & Results & Application \\
\hline $\begin{array}{l}\text { McSpadden } \\
\text { (1998a) }\end{array}$ & $\begin{array}{l}\text { Half-wave dipole } \\
\text { rectenna }\end{array}$ & $\begin{array}{l}\text { Half-wave dipole } \\
\text { and GaAs } \\
\text { IMPATT diode }\end{array}$ & Not available & $\begin{array}{c}85 \% \text { conversion efficiency } \\
\text { across } 165 \Omega \text { resistive load } \\
\text { at } 2.45 \mathrm{GHz}\end{array}$ & $\begin{array}{l}\text { Microwave } \\
\text { power } \\
\text { transmission }\end{array}$ \\
\hline $\begin{array}{l}\text { McSpadden } \\
\text { (1998b) }\end{array}$ & $\begin{array}{l}\text { Half-wave dipole } \\
\text { rectenna }\end{array}$ & $\begin{array}{c}\text { Half -wave } \\
\text { dipole and } \\
\text { MA40150119 Si } \\
\text { Schottky diode }\end{array}$ & $50 \mathrm{~mW}$ & $\begin{array}{c}82 \% \text { conversion efficiency } \\
\text { across } 327 \Omega \text { load resistor } \\
\text { at } 5.8 \mathrm{GHz}\end{array}$ & $\begin{array}{l}\text { Microwave } \\
\text { power } \\
\text { transmission }\end{array}$ \\
\hline $\begin{array}{l}\text { Gomez } \\
(2004)\end{array}$ & $\begin{array}{l}\text { E-pHEMT } \\
\text { technology } \\
\text { rectenna }\end{array}$ & $\begin{array}{l}\text { Microstrip } \\
\text { antenna and an E- } \\
\text { pHEMT detector }\end{array}$ & $14.12 \mathrm{~mW}$ & $\begin{array}{c}85.4 \% \text { overall efficiency at } \\
900 \mathrm{MHz}\end{array}$ & $\begin{array}{c}\text { Microwave } \\
\text { power } \\
\text { transmission, } \\
\text { Actuators and } \\
\text { RFID sensors }\end{array}$ \\
\hline $\begin{array}{c}\text { Suh and } \\
\text { Chang (2002) }\end{array}$ & $\begin{array}{l}\text { Dual-frequency } \\
\text { rectenna }\end{array}$ & $\begin{array}{c}\text { Dual-frequency } \\
\text { dipole and } \\
\text { MA4E1317 } \\
\text { GaAsSchottky } \\
\text { diode }\end{array}$ & $\begin{array}{c}89.84 \mathrm{~mW} \text { at } \\
2.45 \mathrm{GHz} \\
, 49.09 \mathrm{~mW} \text { at } \\
5.8 \mathrm{GHz}\end{array}$ & $\begin{array}{c}84.4 \% \text { efficiency at } \\
2.45 \mathrm{GHz} \text { and } 82 \% \text { at } \\
5.8 \mathrm{GHz}\end{array}$ & $\begin{array}{l}\text { Microwave } \\
\text { power } \\
\text { transmission }\end{array}$ \\
\hline $\begin{array}{c}\text { Heikkinen } \\
\text { and kivikoski } \\
\text { (2003) }\end{array}$ & $\begin{array}{l}\text { Dual-frequency } \\
\text { rectenna }\end{array}$ & $\begin{array}{c}\text { Shorted ring-slot } \\
\text { and HSMS-2862 } \\
\text { Si Schottky diode } \\
\text { pair }\end{array}$ & $-5 \mathrm{dBm}$ & $\begin{array}{c}49 \% \text { efficiency at } \\
2.45 \mathrm{GHz} \text { and } 14 \% \text { at } \\
5.8 \mathrm{GHz}\end{array}$ & $\begin{array}{l}\text { Microwave } \\
\text { power } \\
\text { transmission }\end{array}$ \\
\hline $\begin{array}{c}\text { Strasner and } \\
\text { Chang (2002) }\end{array}$ & $\begin{array}{c}\text { Circularly } \\
\text { polarisedrectenna }\end{array}$ & $\begin{array}{c}\text { DLRA and } \\
\text { MA4E1317 } \\
\text { detector diode }\end{array}$ & Not available & $\begin{array}{c}80 \% \text { conversion efficiency } \\
\text { at } 5.8 \mathrm{GHz} \text { across a } 250 \Omega \\
\text { load resistor }\end{array}$ & $\begin{array}{l}\text { Microwave } \\
\text { power } \\
\text { transmission }\end{array}$ \\
\hline $\begin{array}{c}\text { Strasner and } \\
\text { Chang (2003) }\end{array}$ & $\begin{array}{c}\text { Circularly } \\
\text { polarisedrectenna }\end{array}$ & $\begin{array}{l}\text { Folded dipole and } \\
\text { MA4E1317 } \\
\text { schottky diode }\end{array}$ & $\begin{array}{c}2 \mathrm{~mW} / \mathrm{cm}^{2}(11 \\
5 \mathrm{~mW})\end{array}$ & $\begin{array}{c}82 \% \text { efficiency at } 5.8 \mathrm{GHz} \\
\text { for a } 150 \Omega \text { load }\end{array}$ & $\begin{array}{l}\text { Microwave } \\
\text { power } \\
\text { transmission }\end{array}$ \\
\hline Park (2004) & $\begin{array}{c}\text { Circularly } \\
\text { polarisedrectenna }\end{array}$ & $\begin{array}{l}\text { Circular sector } \\
\text { and HSMS-2820 } \\
\text { schottky diode }\end{array}$ & $10 \mathrm{dBm}$ & $\begin{array}{c}77.8 \% \text { efficiency at } \\
2.4 \mathrm{GHz} \text { across } 150 \Omega \text { load } \\
\text { resistor }\end{array}$ & Not available \\
\hline $\begin{array}{l}\text { Hagerty } \\
(2004)\end{array}$ & $\begin{array}{c}\text { Circularly } \\
\text { polarisedrectenna }\end{array}$ & $\begin{array}{c}\text { Equiangular } \\
\text { spiral and } \\
\text { SMS7630-079 } \\
\text { Schottky diode }\end{array}$ & $0.1 \mathrm{~mW} / \mathrm{cm}^{2}$ & $\begin{array}{l}20 \% \text { rectification } \\
\text { efficiency }\end{array}$ & $\begin{array}{c}\text { Indoor sensor } \\
\text { networks and } \\
\text { energy } \\
\text { recycling }\end{array}$ \\
\hline
\end{tabular}




\begin{tabular}{|c|c|c|c|c|c|}
\hline Ali (2005) & $\begin{array}{c}\text { Circularly } \\
\text { polarisedrectenna }\end{array}$ & $\begin{array}{l}\text { Patch antenna and } \\
\text { MA4E1317 } \\
\text { detector }\end{array}$ & $2.55 \mathrm{~mW} / \mathrm{cm}^{2}$ & $\begin{array}{l}57.3 \% \text { conversion } \\
\text { efficiency at } 5.5 \mathrm{GHz} \text { for } \\
300 \Omega \text { load impedance }\end{array}$ & $\begin{array}{c}\text { Embedded } \\
\text { wireless } \\
\text { sensor and } \\
\text { data telemetry }\end{array}$ \\
\hline $\begin{array}{c}\text { Ren and } \\
\text { Chang (2006) }\end{array}$ & $\begin{array}{c}\text { Circularly } \\
\text { polarisedrectenna }\end{array}$ & $\begin{array}{c}\text { Truncated patch } \\
\text { and two model } \\
\text { MA4E1317 } \\
\text { Schottky diodes } \\
\end{array}$ & Not available & $\begin{array}{l}76 \% \text { efficiency at } 5.8 \mathrm{GHz} \\
\text { for } 100 \Omega \text { loading and } \\
6.22 \mathrm{~V} \text { DC output voltage }\end{array}$ & $\begin{array}{l}\text { Microwave } \\
\text { power } \\
\text { transmission }\end{array}$ \\
\hline Chin (2005) & $\begin{array}{l}\text { FG-CPW } \\
\text { rectenna }\end{array}$ & $\begin{array}{l}\text { Patch antenna and } \\
\text { HSMS-8202 } \\
\text { Schottky diode }\end{array}$ & $18 \mathrm{dBm}$ & $\begin{array}{l}68.5 \% \text { conversion } \\
\text { efficiency at } 5.8 \mathrm{GHz}\end{array}$ & $\begin{array}{l}\text { Microwave } \\
\text { power } \\
\text { transmission } \\
\text { and RFID } \\
\text { sensors }\end{array}$ \\
\hline $\begin{array}{l}\text { Akkermans } \\
\quad(2005)\end{array}$ & $\begin{array}{l}\text { Probe-fed } \\
\text { microstrip patch } \\
\text { rectenna }\end{array}$ & $\begin{array}{l}\text { Microstrip patch } \\
\text { and HSMS-2852 } \\
\text { Schottky diode }\end{array}$ & $0 \mathrm{dBm}$ & $\begin{array}{c}40 \% \text { conversion efficiency } \\
\text { across } 470 \Omega\end{array}$ & $\begin{array}{l}\text { Low-power } \\
\text { wireless } \\
\text { sensor }\end{array}$ \\
\hline Zbitou (2006) & Hybrid rectenna & $\begin{array}{l}\text { Patch antenna } \\
\text { array and } \\
\text { HSMS2820 } \\
\text { Schottkydide }\end{array}$ & $-20 \mathrm{dBm}$ & $\begin{array}{c}20 \% \text { conversion efficiency } \\
\text { at } 2.45 \mathrm{GHz}\end{array}$ & Not available \\
\hline
\end{tabular}

\section{Rectifier}

Rectifier circuits provide a DC output voltage at the load. There are three main options for the rectifier:

- a diode (Figure 3(a))

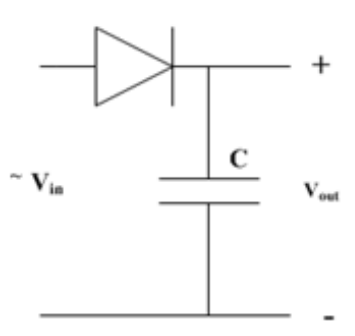

(a)

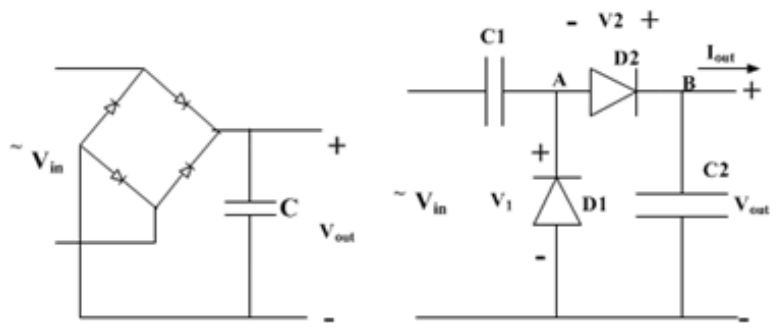

(b)

(c)

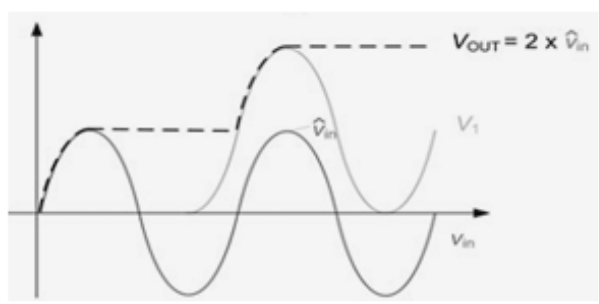

(d)

Figure 3. (a) diode, (b) bridge of diodes, (c) a voltage multiplier rectifier and (d) its waveforms during the transient

The diode and bridge diode provide an output $\mathrm{DC}$ voltage to the load ( $\left.\mathrm{V}_{\text {OuT }}\right)$ whose amplitude is lower than that of the incoming signal. The voltage rectifier is a multiplier, as the name indicates, it multiples the peak amplitude of the incoming signal. At long distances, the DC voltage level is not high enough to power an electronic circuit, so the voltage rectifier multiplier is used. 


\section{Structure of Patch Antenna}

Microstrip patch antennas having low profile are growing popularity to be used in wireless applications. They are suitable for embedded antennas in handheld wireless devices for example cellular phone. Compared to the standard dipole and another monopole antenna, patch antennas are cheaper; provide better and high directional gain performance in a small package. Some of the characteristics of microstrip patch antenna compared to dipole antenna is shown in Table 2.

Table 2. Characteristics of microstrip patch antenne

\begin{tabular}{|c|c|c|}
\hline Characteristics & $\begin{array}{c}\text { Microstrip } \\
\text { Patch Antenna }\end{array}$ & $\begin{array}{c}\text { Printed Dipole } \\
\text { Antenna }\end{array}$ \\
\hline Profile & Thin & Thin \\
\hline Fabrication & Very easy & Easy \\
\hline Polarization & $\begin{array}{c}\text { Both linear and } \\
\text { circular }\end{array}$ & Linear \\
\hline Shape Flexibility & Any shape & $\begin{array}{c}\text { Rectangular and } \\
\text { triangular }\end{array}$ \\
\hline Bandwidth & $2-50 \%$ & $\sim 30 \%$ \\
\hline
\end{tabular}

While designing dipole antenna, there is a problem in coupling between antenna and feed circuit so microstrip patch antenna has been chosen. The microstrip patch antenna is a layered structure consisting of a very thin layer of metallic strips (patch) placed over a thin layer of dielectric substrate with relative permittivity $\varepsilon_{\mathrm{r}}$. The bottom side of the substrate is a conductive layer acting as a ground plane. The dimension of patch is usually a fraction of the wavelength and the thickness of the dielectric substrate layer is usually a small fraction of a wavelength. The shape of the patch could be any geometrical structure, but commonly used are rectangular (square), elliptical (circular or annual ring). Diagram of a rectangular patch antenna and its dimension is given by the patch length (L) and width (W), is given in Figure 4 and Figure 5.

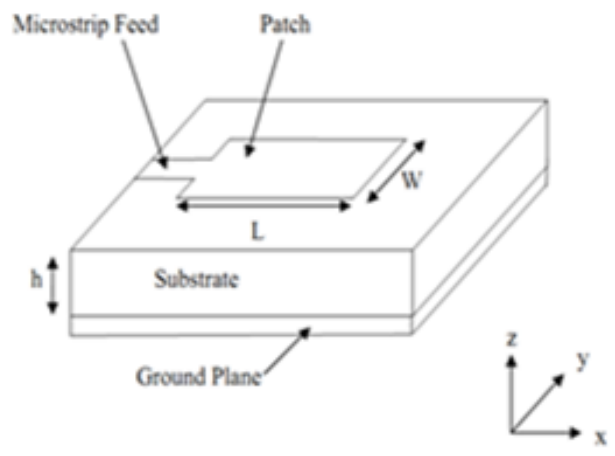

Figure 4. 3D view of rectangular patch antenna 

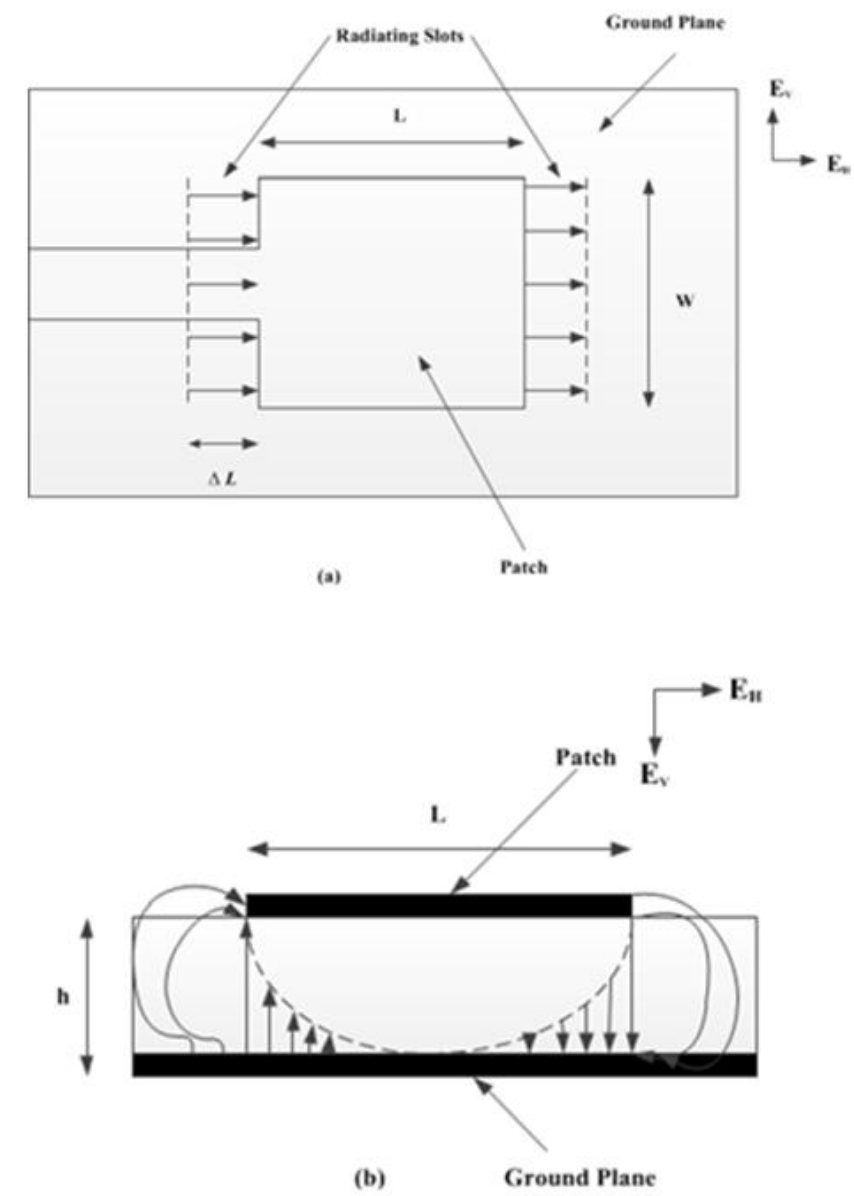

Figure 5. (a) Top and (b) Side view of patch antenna

For a rectangular patch, the length $\mathrm{L}$ of the patch is usually $0.3333 \lambda_{0}<\mathrm{L}<0.5 \lambda_{0}$ where $\lambda_{0}$ is the free-space wavelength. The patch is selected to be very thin such that $t$ $<<\lambda_{0}$ (where $\mathrm{t}$ is the patch thickness). The height $(\mathrm{h})$ of the dielectric substrate is usually $0.003 \lambda_{0} \leq \mathrm{h} \leq 0.05 \lambda_{0}$. The dielectric constant of the substrate usually falls in the range $2.2 \leq \varepsilon_{\mathrm{r}} \leq 12$. Microstrip patch antennas radiate because of the fringing fields $(\Delta \mathrm{L})$ between the ground plane and the patch edge. For better antenna performance, a thick dielectric substrate having a low dielectric constant is necessary as it gives better efficiency, large bandwidth and better radiation. But the size of the antenna is increased so as to design a compact microstrip patch antenna; higher dielectric constants must be used.

\subsection{Some Advantages of Patch Antenna}

- Light weight and low volume

- Low profile planar configuration which can be easily made conformal to host surface

- Low fabrication cost that can be manufactured in large quantities

- Supports linear as well as circular polarization

- Can be easily integrated with microwave integrated circuits (MICs) 
- Capable of dual and triple frequency operations

- Mechanically robust when mounted on rigid surfaces

\subsection{Some Disadvantages of Patch Antenna}

- Low Gain

- Low efficiency

- Narrow bandwidth

- Surface wave excitation

- Low power handling capacity

- Extraneous radiation from feeds and junctions

- Poor end fire radiator except tapered slot antennas

Microstrip patch antennas have a very high antenna quality factory $(\mathrm{Q})$ where $\mathrm{Q}$ represents the losses associated with the antenna and a large $Q$ leads to narrow bandwidth and low efficiency. By increasing the thickness of the dielectric substrate, Q can be reduced. But due to the thickness increases, an increasing fraction of the total power delivered by the source goes into a surface wave. This surface wave contribution can be counted as an unwanted power loss since it is ultimately scattered at the dielectric bends and causes degradation of the antenna characteristics. As a solution, surface waves can be minimized by use of photonic band gap structures. Other problems such as lower power handling capacity and lower gain can be overcome by using an array configuration for the elements.

\section{Conclusion}

In this paper we try to explain some reviews for electromagnetic energy harvesting. The brief explanation of components of rectenna has been given along with ambient source of energy and comparison between microstrip patch and dipole antenna. Also try to mention comparative summary of design of rectenna for electromagnetic energy harvesting. Electromagnetic energy harvesting is the emerging field in today's world so most of the researchers are looking for new technology to harvest electromagnetic energy using different types and design of antenna. Many researches have been done and continuously going on for the betterment of future electromagnetic energy harvesting technique.

\section{Acknowledgements}

This research is supported by Basic Science Research Program through the National Research Foundation of Korea (NRF) funded by the Ministry of Education, Science and Technology (2012005496). And this research was supported partially by the MSIP (Ministry of Science, ICT and Future Planning), Korea, under the C-ITRC (Convergence Information Technology Research Centre) support program (NIPA-2013-H0401-13-2006) supervised by the NIPA (National IT Industry Promotion Agency).

\section{References}

[1] E. F. Little, J. O. McSpadden, K. Chang and N. Kaya, "Toward Space Solar Power: Wireless Energy Transmission Experiments Past”, Present and Future, AIP Conf. Proc., vol. 420, (1998), pp. 1225-1233. 
[2] W. C. Brown, "The receiving antenna and microwave power rectification", Journal of Microwave Power, vol. 5, (1970), pp. 279-92.

[3] W. C. Brown, "The history of power transmission by radio waves", IEEE Trans. Microw. Theory Tech., vol. MTT-32, no. 9, (1984) September, pp. 1230-1242.

[4] Y . H. Suh and K. Chang, "A high efficiency dual frequency rectenna for 2.45- and 5.8-GHz wireless power transmission. IEEE Trans.Microw", Theory Tech., vol. 50, no. 7, (2002) June, pp. 1784-1789.

[5] J. A. Hagerty, F. B. Helmbrecht, W. H. McCalpin, R. Zane and Z. B. Popovic, "Recycling ambient microwave energy with broadband rectenna arrays", IEEE Trans. Microw. Theory Tech., vol. 52, no. 3, (2004) March, pp. 1014-1024.

[6] T. Paing, J. Morroni, A. Dolgov, J. Shin, J. Brannan, R. Zane and Z. Popovic, "Wirelessly-powered wireless sensor platform”, In Proc.EuWiT, Munich, Germany, (2007) October, pp. 241-244.

[7] www.wirelesspowerplanet.com

[8] E. D. Mantiply, K. R. Pohl, S. W. Poppell and J. A. Murphy, "Summary of measured radiofrequency electric and magnetic fields (10 kHz to $30 \mathrm{GHz})$ in the general and work environment", Bioelectromagnetics, vol. 18, Issue 8, (1997), pp. 563 - 577.

[9] Federal Communications Commission (FCC) Codes of Regulation, U.S., Part 15, Low Power Broadcasting, available at www.fcc.gov.

[10] T. T. Le, "Efficient Power Conversion Interface Circuits for Energy Harvesting Applications", Doctor of Philosophy Thesis, Oregon State University, USA, (2008).

[11] H. S. Cho, Y. Yu. Cho, C. S. Shin and J. W. Park, "A Study on Renewable Energy Harvesting and Circuit Design Based on a Maximum Power Point", IJMUE, vol. 8, no. 2, (2013).

[12] J. Park, H. Kim, C. Shin, K. Cho, Y. Cho and K. Kim, "The Effect of Switch Triggering Offset and Switch on-time Duration on Harvested Power in Synchronized Switch Harvesting on Inductor”, IJSH, vol. 7, no. 3 (2013).

[13] Y. Jin, R. Wang, H. Huang and L. Sun, "Ubi-PowerMeter: A Novel Paradigm to Reduce Energy Consumption", IJSH, vol. 4, no. 1, (2010).

[14] W. M. Brown and J. N. Heenan, "An experimental microwave-powered helicopter. Raytheon Company", Burlington, MA, USA, IEEE International Record, vol. 13, part 5, (1965) March, pp. 225-235.

[15] R. M. Dickinson, "Evaluation of a microwave high-power reception-conversion array for wireless power transmission", Jet Propulsion Laboratory, California Institute of Technology, Pasadena, CA, Tech. Memo 336741, (1975) September.

[16] H. Hayami, M. Nakamura and K. Yoshioka, "The Life Cycle CO2 Emission Performance of the DOE/NASA Solar Power Satellite System: A Comparison of Alternative Power Generation Systems in Japan”, IEEE Transactions On Systems, Man, And Cybernetics Part C: Applications And Reviews, vol. 35, no. 3, (2005) August.

[17] T. W. R. East, "Self-steering. self-focusing phased array for SHARP", Antennas and Propagation Society International Symposium. AP6S. Digest 24628, vol. 3, (1991) June, pp. 1732 -1735.

[18] Y. Dong-Gi, P. Yang-Ha, K. Kwan-Ho and R. Young-Chul, "A Study on the Fundamental Transmission Experiment for Wireless Power Transmission System", IEEE TENCON, (1999).

[19] J. Degenford, W. Sirkis and W. Steier, "The reflecting beam waveguide. IEEE Tran. Microwave Theory Tech., (1964) July, pp. 445-453.

[20] R. J. Gutmann and R. B. Gworek, "Yagi-uda receiving elements in microwave power transmission system rectennas", Journal of Microwave Power, vol. 14, no. 4, (1979), pp. 313-320.

[21] N. Shinohara, S. Kunimi, T. Miura, H. Matsumoto and T. Fujiwara, "Open experiment of microwave power experiment with automatically Target Chasing System”, IEICE Trans. B-II, vol .J8I-B-II, no. 6, (1998), pp. 657-661.

[22] T. Ito, Y. Fujino and M. Fujita, "Fundamental experiment of a rectenna array for microwave power reception", IEICE Trans. Commun., E-76-B, no.12, (1993), pp. 1508-1513.

[23] Y. Fujino, M. Fujita, N. Kaya, S. Kunimi, M. Ishii, N. Ogihata, N. Kusaka and S. Ida, "A dual polarization microwave power transmission system for microwave propelled airship experiment”, Proc. de ISAP'96, vol. 2, (1996), pp. 393-396.

[24] T. Shibata, Y. Aoki, M. Otsuka, T. Idogaki and T. Hattori, "Microwave Energy Transmission System for Microrobot”, IEICE-Trans. Electr., vol. 80-C, no.2, (1997), pp. 303-308.

[25] B. Strassner and K. Chang, "5.8-GHz Circularly Polarized Rectifying Antenna for Wireless Microwave Power Transmission", IEEE Trans. MTT, vol. 50, no.8, (2002), pp. 1870-1876.

[26] C. K. Chin, Q. Xue, and C. H. Chan. Design of a 5.8-GHz Rectenna Incorporating a New Patch Antenna. IEEE Antenna and Wireless Propagation Lett., vol. 4, (2005), pp. 175-178.

[27] J. A. Hagerty, N. D. Lopez, B. Popovic and Z. Popovic. Broadband Rectenna Arrays for Randomly Polarized Incident Waves. Proc. of 30th European Microwave Conference, EuMC_JHnlBP_00.pdf, (2000) 
[28] Y. Fujino and K. Ogimura. A Rectangular Parabola Rectenna with Elliptical Beam for SPS Test Satellite Experiment. Proc. of the Institute of Electronics, Information and Communication Engineers, SBC-1-10, (2004), pp. S29-S20.

[29] A. Alden and T. Ohno, "Single Foreplane high Power Rectenna", Electronics Letters, vol. 21, no. 11, (1992), pp. 1072-1073.

[30] J. O. McSpadden and K. Chang, "A Dual Polarized Circular Patch Rectifying Antenna at $2.45 \mathrm{GHz}$ for Microwave Power Conversion and Detection”, IEEE MTT-S Digest, (1994), pp. 1749-1752.

[31] Y. Fujino, M. Fujita, N. Kaya, S. Kunimi, M. Ishii, N. Ogihata, N. Kusaka and S. Ida, "A Dual Polarization Microwave Power Transmission System for Microwave propelled Airship Experiment", Proc. of ISAP 96, vol. 2, (1996), pp. 393-396.

[32] T. Saka, Y. Fujino, M. Fujita and N. Kaya, “An Experiment of a C Band Rectenna”, Proc. Of SPS 97, (1997), pp. 251-253.

[33] P. Leroy, G. Akoun, B. Essakhi, L. Santandrea, L. Pichon and C. Guyot, "An efficient global analysis of a rectenna using the combination of a full-wave model and a rational approximation”, Eur. Phys. J. Appl. Phys. no. 29, (2005), pp. 39-43.

[34] C. H. K. Chin, Q. Xue and C. H. Chan, "Design of a 5.8-GHz Rectenna Incorporating a New Patch Antenna", IEEE Antenna and Wireless Propagation Lett., vol. 4, (2005), pp. 175-178.

[35] W. C. Brown, "The History of the Development of the Rectenna", Proc. Of SPS microwave systems workshop at JSC-NASA, (1980) January 15-18, pp. 271-280.

[36] N. Shinohara and H. Matsumoto, "Experimental Study of Large Rectenna Array for Microwave Energy Transmission”, IEEE Tans. MTT, vol. 46, no. 3, (1998), pp. 261-268.

[37] P. Leroy, G. Akoun, B. Essakhi, L. Santandrea, L. Pichon and C. Guyot, "An efficient global analysis of a rectenna using the combination of a full-wave model and a rational approximation", Eur. Phys. J. Appl. Phys. no. 29, (2005), pp. 39-43.

[38] Y. H. Suh and K. Chang, "A Novel Low-Cost High-Conversion Efficiency Microwave Power Detector Using GaAs FET”, Microwave and Optical Tech. Lett., vol. 44, no. 1, (2005), pp. 29-31.

[39] C. Gómez, J. A. García, A. Mediavilla and A. Tazón, "A High Efficiency Rectenna Element using E-pHEMT Technology”, Proc. of 12th GAAS Symposium, (2004), pp. 315-318.

[40] www.emeraldinsight.com.

[41] R. Selvakumaran, W. Liu, B.-H. Soong, L. Ming and Y. L. Sum, "Design of low power rectenna for wireless power transfer”, Tencon 2009 IEEE region 10 Conf., Singapore, (2009) January, pp. 1-5.

\section{Authors}

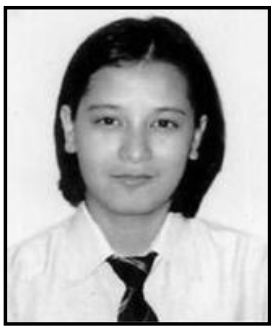

\section{Sajina Pradhan}

Sajina Pradhan received M.S. degree in the Department of Information and Communication Engineering from Chosun University, Gwangju, Korea in 2012. Since 2012, she has been an Ph.D. student in the Department of Mechatronics Engineering from Chosun University, Gwangju, Korea. The research areas of interest are Signal processing, RF energy harvesting devices, designs and applications.

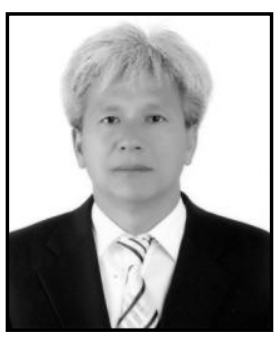

\section{Seong Ro Lee}

Seong Ro Lee received the B.S. degree in electronics engineering from Korea University, Seoul, Korea, in 1987, and the M.S., and $\mathrm{Ph} . \mathrm{D}$. degrees in electrical engineering from Korea Advanced Institute of Science and Technology, Daejeon, Korea, 1990 and 1996, respectively. In September 1997, he joined the Division of Electronics Engineering, Mokpo National University, Jeonnam, Korea. His research interests include digital communication system, 
mobile and satellite communications system, applications of telematics, USN and embedded system.

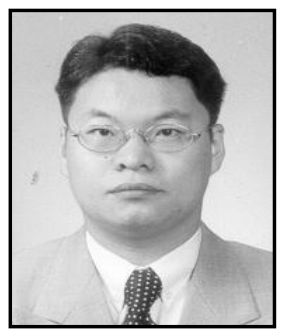

\section{Sun-Kuk Noh}

Sun-Kuk Noh received his B.Sc., the M.Sc., and the D.Sc. degrees in Electronics Engineering from Chosun University of Gwangju, Republic of Korea, in 1995, 1997, and 2000, respectively. From March 2002 to August 2004, he was a Research Professor in the Division of Electronics and Information Engineering, Chonbuk National University, Republic of Korea. From Sept. 2004 to Feb. 2012, he has been an assistant professor in the Department of Mobile Communications Engineering, Honam University, Gwangju, Korea. Since Oct. 2012, he is an assistant professor in the dept. of Photoelectronics Information, Chosun College of Science \& Technology, GwangJu, Republic of Korea. His major research interests include mobile communications, radiowave propagation, DMB, RFID, Antenna, and NFC. He is a Member of IEEE, JCN, IEEK, and KICS.

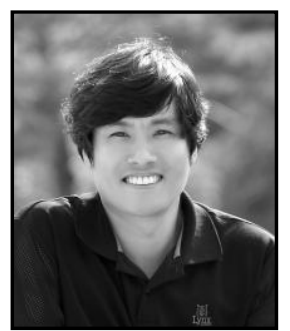

\section{Dong-You Choi}

Dong-You Choi was born in Seoul, Korea, on February 25, 1971. He received the B.S., M.S. and Ph.D. degree in the Department of Electronic Engineering from Chosun University, Gwangju, Korea in 1999, 2001, and 2004, respectively. Since 2007, he has been taught and researched as a professor at Chosun University. His research interests include mobile communication and wave propagation. He is a member of IEEE, IEICE, JCN, KEES, IEEK, KICS, and ASK. 
International Journal of Control and Automation Vol.7, No.3 (2014) 